\title{
THE COST AS THE MAIN DETERMINANT OF THE LOCATION OF LOGSTICS CENTERS
}

\author{
Agnieszka Tłuczak ${ }^{1}$, Sabina Kauf ${ }^{2}$
}

\begin{abstract}
Apropriate location of the logistics center allows entrepreneurs to significantly reduce the costs of transport. On the other hand, it has a positive impact on the development of the transport infrastructure of the region.

This paper presents the practical aspects of the localization problem of logistics center with the use of a geographic information system. It shows differences between theoretical models, the needs of decision-makers, and the data available to make the necessary calculations. The results of computational experiments were introduced to illustrate the effects of this approach.
\end{abstract}

JEL Classification Numbers: C44, C02, D2; DOI: http://dx.doi.org/10.12955/cbup.v6.1201

Keywords: costs, center of gravity method, localization, logistics centers

\section{Introduction}

The idea of logistic centers is gaining more and more importance for enterprises that are trying to minimalize operational costs, they want to reduce the negative phenomena of congestion. Logistic centers are an element that supports the realization of the concept of a logistic area, that's why they are often connected each other (Bretzke, 1993). Creation of logistic centers is the answer for economical, ecological and urban problems, not only for small but also metropolitan areas (Tundys, 2008).

The main aim of existing a logistic center is to minimize transportation cost at its area. The location of logistic centers is a key for increasing the productivity of the urban transportation system. The goal for solving the problems associated with the location of objects, is setting its location in a way that the sum of the operational costs of the system is as low as possible. In addition, its necessary to peg a minimal number of objects in a distribution net to gain a set level of customer service. An Important element of distribution nets are logistic centres. Nowadays when choosing a location of logistic centre we pay attention to natural, technical, techno-economic, social and political aspects. In addition, when choosing the location of production factories, we pay attention to these following elements: the stability of the economy and the level of risk, the possibility of social conflicts, influence of trade unions, the attitude of environment to the designed investment and its future production, the condition of the natural environment and the size and structure of taxes (Kayicki, 2010).

Studies of preference of location for enterprises can be useful in creating business parks and industry areas. Different types of studies of this topic focus on various elements of the decision about a location. Many evolutionary and institutional trials try to show a need to encircle in this area. (Pellenbarg, 2006). Different, more neoclassical theories focus on the costs of transportation and employment. The necessity to find optimal location of logistic center has been taken under consideration of many authors; they obtained different results (Pellenbarg, 2006, Engelen, 2017).

The first theory of location was formed in the beginning of 20th century by Alfred Weber (Weber, 1929According to this theory the enterprise should be located in this place where costs of feedstock of transportation, ready products and costs of work are lowest. Weber's theory has been criticised by the makers of costs and demand theories of locations based on the thesis on spatial differentiation of costs of goods (Weber, 1929).

For the last 3 decades many of methods used for setting a location have evolved. Depending on the problem there are a few methods: The un-hierarchical method of analysis of focusing, Huff's model, the radius of area of gravity, the net method and model of gravity of Reilly's trade. Detailed descriptions of use of these methods can be found in the articles by Perales (2002), Anderson et al. (2010), Friske et al. (2013), Huff, Rust (1984) and Reilly's (1953). Applying analytical methods to solve the problem of location is limited because of simple problems, more difficult ones need to use heuristics methods. For the first time, the problem of choosing a location had been undertaken in Weber's work, then Cooper and in last few years it is undertaken by more and more people who find new, better methods to solve the problem (Weber 1929, Cooper 1963, Cooper 1964, Farahani at all.

\footnotetext{
${ }^{1}$ Opole University, atluczak @uni.opole.pl

${ }^{2}$ Opole University, skauf@uni.opole.pl
} 
2010; Tomic at all., 2013; Mayer and Wagner, 2002, Glover, 1993; Chi and Kuo, 2001; Kayicki, 2010).

Chopra and Meindl (2007) argue that proper location of a logistics center can improve the functioning of the supply chain. A bad location may make it impossible to achieve the desired level of satisfaction with services. The logistics center should be located in such a way that all the suppliers and customers are satisfied in the best extent, with the lowest possible costs. Boone et al., (2008) describe the distribution decision as crucial to provide the necessary flexibility to meet customer requirements and achieve the desired level of customer service. Despite the differences, the basic assumptions of the location models always include in the context of analyzes: space, customers and producers whose locations in a given space are known and objects whose locations have to be determined according to a specific purpose function.

\section{Methodology}

\section{Distance functions in location planning}

The classical factor of logistic centers location and different model points of logistic nets are costs. That's why we will also consider the choice of location of logistic centers depending on the costs of delivery. For this purpose, we will use a mathematical model in which a parameter will be a distance. Often, the presented models for the evaluation of distance with use of the presented problems are described by formulas (Kauf, Tłuczak, 2014; Kuczyńska, Ziółkowski, 2011):

$$
\begin{aligned}
& d_{i j}^{p}=\left|x_{i}-x_{j}\right|+\left|y_{i}-y_{j}\right| \\
& d_{i j}^{p}=\sqrt{\left(x_{i}-x_{j}\right)^{2}+\left(y_{i}-y_{j}\right)^{2}}
\end{aligned}
$$

where:

$\mathrm{d}_{\mathrm{e}}=$ Euclidean distance; $\mathrm{x}_{1}=\mathrm{x}$ coordinate of point $\mathrm{A} ; \mathrm{y}_{1}=\mathrm{y}$ coordinate of point $\mathrm{A} ; \mathrm{x}_{2}=\mathrm{x}$ coordinate of point $\mathrm{B} ; \mathrm{y}_{2}=\mathrm{y}$ coordinate of point $\mathrm{B}$.

Formula (1) shows urban metrics (rectangular), in which distance is a sum of level length (horizontal) and vertical, usually understood as Euclidean distance is presented with Formula 2. Differences in interpretation of both metrics are shown in Figure 1. Usually actual distance between points is smaller than the distance set by using urban metrics and not shorter than distance set by Euclidean metrics.

Mwemezi and Huang (2011) state that by using spherical trigonometry, it is possible to get more realistic distance measurement (Krawczyk, 2001; Walerjańczyk 2010). In real life and especially in road transportation, travelling along a straight lines is not possible, that's why an Euclidean measurement is often more reasonable than the rectilinear measurement.

Figure 1: Rectilinear and Euclidean distance between points $\mathrm{A}$ and $\mathrm{B}$

\section{Cost function}

A distribution center distributes the goods to multiple distribution points. The goal is to find the optimal distribution center location where the total cost can be minimized, when the location of the 
distribution points is known. Shorter distances mean lower transportation costs almost without exception.

The problem is based on the minimization of the cost function, which is given by the formula (Krawczyk, 2001; Kauf Tłuczak, 2014):

$$
K=\sum_{i=1}^{m} a_{i} k_{i}^{a} d_{i 0}+\sum_{j=1}^{n} b_{j} k_{j}^{b} d j_{i 0}
$$

where :

$A_{i}\left(x_{i}^{A}, y_{i}^{A}\right)$ - location of suppliers; $a_{i}$-expected volume of supplies;

$B_{j}\left(x_{j}^{B}, y_{j}^{B}\right)$ - location of customers; $\mathrm{b}_{\mathrm{j}}$ - expected volume of supply;

$k_{a}^{i}, k_{b}^{j}$ - The unit cost of transporting goods from suppliers $k_{a}^{i}$ to customers $k_{b}^{j}$.

If the Euclidean distance is used, then Formula 3 is given as follow:

$$
K=\sum_{i=1}^{m} a_{i} k_{i}^{A} \sqrt{\left(x_{i}^{A}-x_{0}\right)^{2}+\left(y_{i}^{A}-y_{0}\right)^{2}}+\sum_{j=1}^{n} b_{j} k_{j}^{B} \sqrt{\left(x_{j}^{B}-x_{0}\right)^{2}+\left(y_{j}^{B}-y_{0}\right)^{2}}
$$

and if the rectilinear distance is used to measure the distance then Formula 3 is given by equation:

$$
K=\sum_{i=1}^{m} a_{i} k_{i}^{A}\left[\left|x_{i}^{A}-x_{0}\right|+\left|y_{j}^{A}-y_{0}\right|\right]+\sum_{j=1}^{n} b_{j} k_{j}^{B}\left[\left|x_{i}^{B}-x_{0}\right|+\left|y_{j}^{B}-y_{0}\right|\right]
$$

\section{Center of gravity method}

Setting of coordinates $(\mathrm{x} 0, \mathrm{y} 0)$ needs the setting of the first partial derivatives of a function $\mathrm{K}$ (Formula 4) and equating those derivatives to zero. As a result of the described actions, the sought after data can be set by formulas:

$$
x_{0}=\frac{\sum_{i=1}^{m} \frac{a_{i} k_{i}^{A} x_{i}^{A}}{d_{i}^{A}}+\sum_{j=1}^{n} \frac{b_{j} k_{j}^{B} x_{j}^{B}}{d_{j}^{B}}}{\sum_{i=1}^{m} \frac{a_{i} k_{i}^{A}}{d_{i}^{A}}+\sum_{j=1}^{n} \frac{b_{j} k_{j}^{B}}{d_{j}^{B}}}
$$

$$
y_{0}=\frac{\sum_{i=1}^{m} \frac{a_{i} k_{i}^{A} y_{i}^{A}}{d_{i}^{A}}+\sum_{j=1}^{n} \frac{b_{j} k_{j}^{B} y_{j}^{B}}{d_{j}^{B}}}{\sum_{i=1}^{m} \frac{a_{i} k_{i}^{A}}{d_{i}^{A}}+\sum_{j=1}^{n} \frac{b_{j} k_{j}^{B}}{d_{j}^{B}}}
$$

Because of difficulties in setting the sought after coordinates, in Equation 6 and 7, the variables are on both sides of the equation, to solve it we use iterative methods.

In the first step for the original data, we should set coordinates for the center of gravity according to these formulas:

$$
\begin{gathered}
\bar{x}_{0}=\frac{\sum_{i=1}^{m} a_{i} k_{i}^{A} x_{i}^{A}+\sum_{j=1}^{n} b_{j} k_{j}^{B} x_{j}^{B}}{\sum_{i=1}^{m} a_{i} k_{i}^{A}+\sum_{j=1}^{n} b_{j} k_{j}^{B}} \\
\bar{y}_{0}=\frac{\sum_{i=1}^{m} a_{i} k_{i}^{A} y_{i}^{A}+\sum_{j=1}^{n} b_{j} k_{j}^{B} y_{j}^{B}}{\sum_{i=1}^{m} a_{i} k_{i}^{A}+\sum_{j=1}^{n} b_{j} k_{j}^{B}}
\end{gathered}
$$


Evaluated coordinates are used to calculating the distance

$$
d_{i}=\sqrt{\left(x_{i}-\bar{x}_{0}\right)^{2}+\left(y_{i}-\bar{y}_{0}\right)^{2}}
$$

Distances gained from Formula (2) have to be substituted by Formulas (6) and (7) that allows us to set remediated coordinates $\mathrm{x}_{0} \mathrm{i} \mathrm{y}_{0}$. Calculated remediated variables are our new coordinates $\bar{x}_{0}, \bar{y}_{0}$ and based on the distance, $\mathrm{d}$ is calculated according to Formula 10.

\section{Choice of best logistics centers location: an illustrative example}

Choosing a logistics centers location is not an easy task, and despite the existence of a number of methods and tools for its estimation, no universal method has been developed yet. Let's consider the case of 4 receivers and 5 suppliers from the European Union. The data which present transport volumes and costs of transport are presented in Table 1. The location of consumers and suppliers was determined by geographic coordinates, expressed in decimal degrees (SD - World Geodetic System '84). Our goal is to find the best location for the logistics center, which cooperate with all receivers and suppliers.

\begin{tabular}{|c|c|c|c|c|c|c|c|c|c|c|}
\hline \multirow[t]{2}{*}{ City } & \multirow[t]{2}{*}{$\begin{array}{l}\text { Suppliers / } \\
\text { customers }\end{array}$} & \multirow[t]{2}{*}{$\mathrm{x}_{\mathrm{i}}$} & \multirow[t]{2}{*}{$\mathrm{y}_{\mathrm{i}}$} & $\begin{array}{l}\text { Volume } \\
\text { of } \\
\text { transport } \\
\text { (t) }\end{array}$ & $\begin{array}{l}\text { Cost of } \\
\text { transport } \\
(\mathrm{z} / \mathrm{t})\end{array}$ & $\mathrm{a}_{\mathrm{i}} \mathrm{k}_{\mathrm{i}}$ & $\mathrm{x}_{\mathrm{i}} \mathrm{a}_{\mathrm{i}} \mathrm{k}_{\mathrm{i}}$ & $\mathrm{y}_{\mathrm{i}} \mathrm{a}_{\mathrm{i}} \mathrm{k}_{\mathrm{i}}$ & $\mathrm{d}_{\mathrm{i}}$ & $\mathrm{a}_{\mathrm{i}} \mathrm{k}_{\mathrm{i}} \mathrm{d}_{\mathrm{i}}$ \\
\hline & & & & $\left(a_{i}, b_{j}\right)$ & $\left(\mathrm{k}_{\mathrm{i}}, \mathrm{k}_{\mathrm{j}}\right)$ & $b_{j} k_{j}$ & $x_{j} b_{j} k_{j}$ & $\mathrm{y}_{\mathrm{j}} \mathrm{b}_{\mathrm{j}} \mathrm{k}_{\mathrm{j}}$ & $\mathrm{d}_{\mathrm{j}}$ & $\mathrm{a}_{\mathrm{j}} \mathrm{k}_{\mathrm{j}} \mathrm{d}_{\mathrm{j}}$ \\
\hline Prague & Supplier $A_{1}$ & 14,44 & 50,08 & 0,30 & 41,90 & 12,57 & 181,48 & 629,45 & 1,48 & 18,55 \\
\hline Berlin & Supplier $\mathrm{A}_{2}$ & 13,40 & 52,52 & 2,10 & 52,00 & 109,20 & 1463,82 & 5735,18 & 3,25 & 354,91 \\
\hline Paris & Supplier $\mathrm{A}_{3}$ & 2,35 & 48,86 & 0,40 & 53,40 & 21,36 & 50,24 & 1043,58 & 10,85 & 231,82 \\
\hline Vienna & Supplier $\mathrm{A}_{4}$ & 16,37 & 48,21 & 2,60 & 54,20 & 140,92 & 2307,40 & 6793,50 & 3,35 & 472,33 \\
\hline Warsaw & Supplier $\mathrm{A}_{5}$ & 21,01 & 52,23 & 1,40 & 54,20 & 75,88 & 1594,41 & 3963,19 & 8,35 & 633,95 \\
\hline Bratislava & Customer $\mathrm{B}_{1}$ & 17,11 & 48,15 & 2,40 & 49,70 & 119,28 & 2040,61 & 5743,16 & 4,07 & 485,50 \\
\hline Zurich & Customer $\mathrm{B}_{2}$ & 8,54 & 47,38 & 0,90 & 45,40 & 40,86 & 349,01 & 1935,82 & 5,03 & 205,44 \\
\hline Brussels & Customer $\mathrm{B}_{3}$ & 4,35 & 50,85 & 2,40 & 51,10 & 122,64 & 533,69 & 6236,29 & 8,98 & 1101,81 \\
\hline Rome & Customer $\mathrm{B}_{4}$ & 12,50 & 41,90 & 1,10 & 50,50 & 55,55 & 694,17 & 2327,70 & 7,41 & 411,46 \\
\hline Sum & & & & & & 698,26 & 9214,85 & 34407,86 & & 3915,77 \\
\hline
\end{tabular}

Based on the results we can calculate the coordinates of the center of gravity $\bar{x}_{0}=9214,85 / 698,26=$ 13,20 and $\bar{y}_{0}=34407,86 / 698,26=49,28$. For the designated coordinates of the center of gravity, the cost of transport was calculated, and it is $\mathrm{K}=3915,77$. In the next step, new corrected coordinates should be found, because it can decrease the costs of transport (Table 2).

\begin{tabular}{|l|l|l|l|l|l|}
\hline \multicolumn{5}{|l|}{ Table 2: Auxiliary calculations } \\
\hline \multirow{5}{*}{} & Suppliers / customers & $\left(\mathrm{a}_{\mathrm{i}} \mathrm{k}_{\mathrm{i}} \mathrm{x}_{\mathrm{i}}\right) / \mathrm{d}_{\mathrm{i}}$ & $\left(\mathrm{a}_{\mathrm{i}} \mathrm{k}_{\mathrm{i}} \mathrm{y}_{\mathrm{i}}\right) / \mathrm{d}_{\mathrm{i}}$ & $\left(\mathrm{a}_{\mathrm{i}} \mathrm{k}_{\mathrm{i}}\right) / \mathrm{d}_{\mathrm{i}}$ \\
\cline { 2 - 6 } & & $\left(\mathrm{b}_{\mathrm{j}} \mathrm{k}_{\mathrm{j}} \mathrm{x}_{\mathrm{j}}\right) / \mathrm{d}_{\mathrm{j}}$ & $\left(\mathrm{b}_{\mathrm{j}} \mathrm{k}_{\mathrm{j}} \mathrm{y}_{\mathrm{j}} / \mathrm{d}_{\mathrm{j}}\right.$ & $\left(\mathrm{b}_{\mathrm{j}} \mathrm{k}_{\mathrm{j}}\right) / \mathrm{d}_{\mathrm{j}}$ \\
\cline { 2 - 6 } & City & 12,97 & 426,49 & 8,52 \\
\cline { 2 - 6 } & Prague & Supplier $\mathrm{A}_{1}$ & 450,39 & 1764,62 & 33,60 \\
\cline { 2 - 6 } & Berlin & Supplier $\mathrm{A}_{2}$ & 4,63 & 96,16 & 1,97 \\
\cline { 2 - 6 } & Paris & Supplier $\mathrm{A}_{3}$ & 688,41 & 2026,83 & 42,04 \\
\cline { 2 - 6 } & Vienna & Supplier $\mathrm{A}_{4}$ & 190,84 & 474,37 & 9,08 \\
\cline { 2 - 6 } & Warsaw & Supplier $\mathrm{A}_{5}$ & 501,34 & 1410,99 & 29,30 \\
\cline { 2 - 6 } & Bratislava & Customer $\mathrm{B}_{1}$ & 69,42 & 385,02 & 8,13 \\
\cline { 2 - 6 } & Zurich & Customer $\mathrm{B}_{2}$ & 59,40 & 694,15 & 13,65 \\
\cline { 2 - 6 } & Brussels & Customer $\mathrm{B}_{3}$ & 93,72 & 314,26 & 7,50 \\
\hline & Rome & Customer $\mathrm{B}_{4}$ & 2181,12 & 7592,88 & 153,79 \\
\hline
\end{tabular}

The new coordinates for logistics centers are as follow $\mathrm{x}_{0}=2181,12 / 153,79=14,18$ and $\mathrm{y}_{0}=7592,88 / 153,79=49,37$; the cost of transport is $\mathrm{K}=3795,11$. Doing the same calculation but using a rectangular distance the coordinates of logistics center are given as follow: $\mathrm{x}_{0}=14,51$ and $\mathrm{y}_{0}=49,13$, 
and $\mathrm{K}=3443,85$. Solving the task of searching for the location of a logistics center, three locations were found $\mathrm{P}_{1}(13.20 ; 49.28) ; \mathrm{P}_{2}(14.18 ; 49.37) ; \mathrm{P}_{3}(14.51 ; 49.13)$. Coordinates indicate a places contained on the territory of the Czech Republic, in the neighborhood of Vitin and Vlkov (Figure 2). The lowest transportation costs were obtained with the rectangular distance.

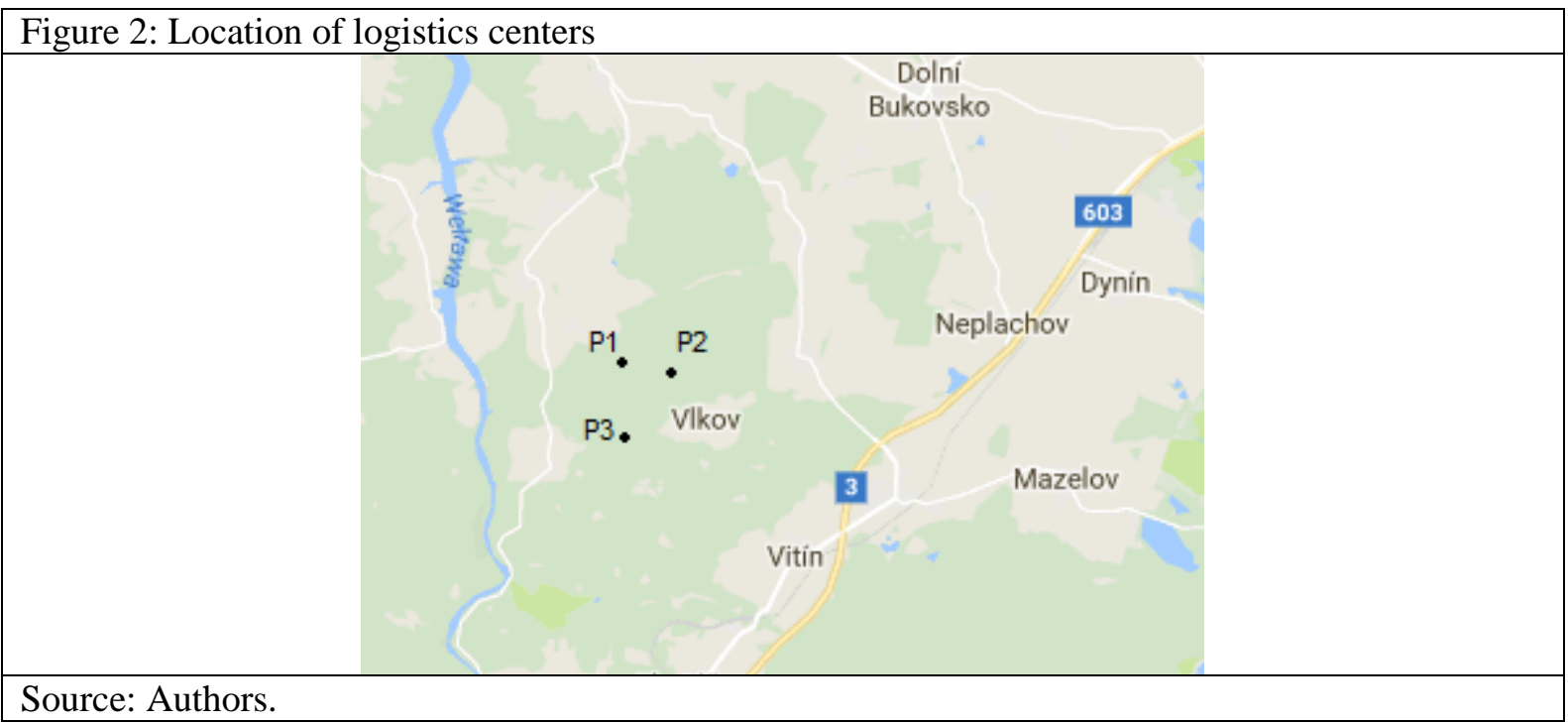

\section{Conclusion}

The presented methods allow us to choose the best location for logistics center from the cost point of view. Authors do realize, however, that taking into account only the cost aspects in choosing a location is a significant simplification of the problem. Nevertheless, these methods allow us to find the optimal solutions. They may however, be applied when other conditions, such as the availability of land for the construction of the center or the existence of a suitable communication infrastructure, are met.

\section{References}

Anderson S.J., Volker J.X., Phillips M.D. (2010) Converse's Breaking-Point Model Revised, Journal of Management \& Marketing Research; Vol. 3, p1

Boone, C. A., Craighead, C. W., Hanna, J. B. (2008) Critical challenges of inventory management in service parts supply: A Delphi study. Operations Management Research, Vol. 1, pp. 31-39.

Bretzke, W.R. (1993) City-Logistik. Problemlosung durch logistische Dienstleistungszentren? Internationales Verkehrswesen vol.12, p. 706.

Chi S.-C., Kuo R.-J. (2001) Examination of the influence of fuzzy analytic hierarchy process in the development of an intelligent location selection support system of convenience store IFSA World Congress and 20th NAFIPS International Conference, 3, pp. 1312-1316

Chopra, S., Meindl, P. (2007) Supply Chain Management: Strategy, Planning, and Operation. 3 rd edition. Pearson Prentice Hall, p. 536

Cooper, L. (1963) Location-Allocation Problems, Operations Research, Vol. 11, No. 3, pp. 331-342.

Cooper, L. (1964) Heuristic methods for location allocation problems, SIAM Review, Vol. 6, No. 1, pp. 37-53.

Engelen C. (2017) E-fulfillment and location decisions, http://gpm.ruhosting.nl/mt/2013-MA-SG-50\%2CEngelenCasper.pdf, access: 1.11 .2017

Farahani, RZ., Steadieseifi, M., Asgari, N. (2010) Multiple criteria facility location problems: A survey, Applied Mathematical Modeling, Vol. 34, No. 7, pp. 1689-1709.

Friske W., Choi S. (2013) Another Look at Retail Gravitation Theory: History, Analysis, and Future Considerations, ABD Journal, Volume 5 Number 1

Glover F., Laguna, M. (1993) Tabu Search. In C. R. Reeves (Ed.), Modern heuristic techniques for combinatorial problems, John Wiley \& Sons, Inc.

Huff, D. L. \& Rust, R.T. (1984). Measuring the congruence of market areas. Journal of Marketing, 48 (Winter), 68-74.

Janic, M., Reggiani, A. (2001) Multi-criteria evaluation of a new hub airport for an EU airline. Presented at the 6th NECTAR Conference held in Helsinki, Finland, May $16-18$.

Kayicki Y. (2001) A conceptual model for intermodal freight logistics centre location decisions, Procedia - Social and Behavioral Sciences, Volume 2, Issue 3, Pages 6297-6311

Kauf S., Tłuczak A. (2014) Logistyka miasta, Difin, Warszawa, p.128 
Krawczyk S. (2001) Metody ilosciowe w logistyce, C.H. Beck, p. 354

Mayer G. , Wagner B. (2002) Hublocator: an exact solution method for the multiple allocation hub location problems, Computers \& Operations Research, 29, pp. 715-739

Mwemezi, J. J., Huang, Y. (2011) Optimal Facility Location on Spherical Surfaces: Algorithm and Application. New York Science Journal, Vol. 4, Iss. 7, pp. 21-28.

Onella N. (2017) Determining The Optimal Distribution Center Location, https://dspace.cc.tut.fi/dpub/bitstream/ handle/123456789/22 938/onnela.pdf;sequence=1, access 1.11.2017

Pellenbarg, P. H. (2006) Locatie of prestatie? Bedrijventerreinen en vestigingskeuze. Stedebouw en Ruimtelijke Ordening, 87, 3, pp. 26-29.

PeralesD. (2002) Conumer Choice in Comptitive Location Model,

http://www.tdx.cat/bitstream/handle/10803/7330/trcp1de1.pdf?sequence=1

Reilly, W. J. (1929). Methods for the study of retail relationships. Austin, TX: Bureau of Business Research.

Reilly, W.J. (1953). The law of retail gravitation (2 nd ed.) New York, NY: Pilsbury Publishers

Tomić V., Memet A., Milosavljević M., Milisavljević S. (2013) Decisions On The Logistic Centers Location, Case Of The Balkan Peninsula, Annals Of The Oradea University Fascicle Of Management And Technological Engineering Issue 2, September

Tundys B. (2008) Logistyka miejska. Koncepcje, systemy, rozwiązania. Difin, Warszawa 2008, s. 179.

Walerjańczyk W. (2010) Zagadnienie lokalizacji centrum dystrybucji a współczesne systemy informacji geograficznej. Logistyka, vol. 6.

Weber, A. (1929) Uber den Standort der Industrien, Tubingen, Theory of the location of industries, University of Chicago Press 